\title{
Impacts of Using Mineral Fertilization Combined with Sewage Sludge in the Amendment of Luvisol on Oat Crop. II. Influence on Metal Accumulation
}

\author{
MIRCEA MIHALACHE ${ }^{1}$, LEONARD ILIE ${ }^{1}$, GINA VASILE SCAETEANU ${ }^{1}$, \\ CATALINA CALIN ${ }^{2}$, ROXANA MARIA MADJAR ${ }^{1 *}$ \\ ${ }^{1}$ University of Agronomic Sciences and Veterinary Medicine of Bucharest, 59 Marasti Blvd., 011461, Bucharest, Romania \\ ${ }^{2}$ Petroleum-Gas University of Ploiești, 39 Bucharest Av., 100680, Ploiesti, Romania
}

\begin{abstract}
The objective of the present paper was to investigate the effects of sewage sludge application on metals (Cu, $\mathrm{Mn}, \mathrm{Zn}, \mathrm{Cd}, \mathrm{Co}, \mathrm{Pb}$ ) accumulation in oat (Avena sativa L.) grains, Someșan variety. It were used various doses of sewage sludge corresponding to equivalent doses of 0-600 $\mathrm{kg} \mathrm{N/ha}$ associated or not with NPK mineral fertilization. The results evidenced that copper and zinc levels in oat grains increased significant with sewage sludge fertilization starting with a dose equivalent with $200 \mathrm{~kg} \mathrm{~N} / \mathrm{ha}$. Mineral fertilization led to significant decrease of copper content in comparison with sewage sludge treatments only. For manganese, fertilization with sewage sludge has produced a significant decrease, this trend being accentuated up to the equivalent dose of $300 \mathrm{~kg} \mathrm{~N} / \mathrm{ha}$. For cadmium, application of sewage sludge in an equivalent dose of $200 \mathrm{~kg} \mathrm{N/ha}$ led to concentrations in oat grains higher than $1 \mathrm{mg} \mathrm{Cd/kg} \mathrm{(imposed} \mathrm{limit} \mathrm{for} \mathrm{grains} \mathrm{used} \mathrm{for} \mathrm{animal} \mathrm{feed).} \mathrm{This} \mathrm{behavior} \mathrm{is} \mathrm{a}$ consequence of high cadmium content of sewage sludge (of 7.2 times over maximum admitted limit). Cobalt contents of oat grains increased with sewage sludge doses, but the levels are between normal values and concordant with literature data. Application of sewage sludge in an equivalent doses of 500 and $600 \mathrm{~kg} \mathrm{~N} / \mathrm{ha}$ generated a significant increase of lead content in oat grains, average values being 1.87 and $2.17 \mathrm{mg} P b / \mathrm{kg}$, respectively.
\end{abstract}

Keywords: accumulation, grains, fertilization, metal, oat, sewage sludge.

\section{Introduction}

Sewage sludge is a semisolid material resulted from sedimentation of the suspended solid during processes which occur at wastewater treatment plants. Its application is very beneficial to soil properties [1] and contain macronutrients suitable for plant nutrition [2,3]. The agronomic importance of sewage sludge is also evidenced by its use as organic fertilizer, many studies emphasizing its efficiency from this point of view. Hence, Tsadilas et al. [4] found that after sewage sludge treatments, the nitrogen content in the dry matter of wheat increased. Morera et al. [5] reported that sludge doses of 80,130 and $160 \mathrm{t} /$ ha increased the average dry weight of sunflower plants (Helianthus annuus L.) in comparison with control variant. Also, fertilization with sewage sludge produced for sunflower plants significant increases of stem, leaves and calatidium mass [6]. Yield of rice increased by $60 \%, 111 \%, 125 \%, 134 \%$ and $137 \%$ at $30,45,60,90$ and 120 t/ha sewage sludge rates, respectively in comparison with those grown in unamended soil [7].

Heavy metal accumulation in agricultural soils after sewage sludge application may lead to pollution but also to crop contamination and to enter in food chain. Application of sewage sludge increased cadmium, lead, copper and zinc levels in soil from 0.23-0.39, 28.16-28.36, 27.01-28.35 and $26.30-27.92 \mathrm{mg} / \mathrm{kg}$ to $0.30-0.60,36-50,30-42$ and $31-43 \mathrm{mg} / \mathrm{kg}$, respectively [8].

\footnotetext{
*email: rmadjar@yahoo.com
} 
It has been demonstrated that plants grown on soils amended with sewage sludge absorb higher quantities of metals in comparison with control variant [9]. As against other nutrient species which may leach or remove with crop, heavy metals may persist in soil for a long time and as consequence, it is possible to produce phytotoxicity which affects plant growth and other metabolic activities [10]. It has been proven that accumulation of heavy metals in plants led to reduced photosynthetic rate and chlorophyll pigments, stunted growth and lowering of yield [11].

Application of sewage sludge with rates over $4.5 \mathrm{t} / \mathrm{ha}$ led for rice crop to accumulation of nickel and cadmium in grains above safe limits, causing food chain contamination [7]. Treatments with increasing doses of sewage sludge $(0,40,80,120$ and $240 \mathrm{t} / \mathrm{ha})$ at rice produced a significant increase of iron, copper, zinc and lead in grains, while the manganese content decreased significantly [12].

As presented, sewage sludge is used for fertilization purposes and some studies present the possible production of sewage sludge based organo-mineral fertilizer [13]. Therefore, the presence of metals in sewage sludge's composition must be strictly monitored and to avoid possible negative effects for environment or for crops, its application it is mandatory to be done under rigorous surveillance $[14,15]$.

As an extension of previously reported results [6, 16-19] and considering the importance of sewage sludge from agronomic point of view, this study emphasizes the effects of various doses sewage sludge on metals $(\mathrm{Cu}, \mathrm{Mn}, \mathrm{Zn}, \mathrm{Cd}, \mathrm{Co}, \mathrm{Pb})$ accumulation for oat (Avena sativa $\mathrm{L}$.) grains.

\section{Materials and methods}

\subsection{Experimental design}

The aim of undertaken study was to investigate the influence of sewage sludge application on metal accumulation $(\mathrm{Cu}, \mathrm{Mn}, \mathrm{Zn}, \mathrm{Cd}, \mathrm{Co}, \mathrm{Pb})$ in the case of oat crop (Avena sativa $\mathrm{L}$.), Someșan variety.

For experimental purposes, it was designed a bifactorial experimental model $(7 \times 2)$, this meaning 7 fertilization levels with sewage sludge combined with 2 levels of mineral fertilization, in 4 repetitions, totalizing 56 vegetation pots ( $20 \mathrm{~L}$ capacity each).

Each pot was filled with soil collected from $A_{0}$ horizon of luvisol meanwhile sewage sludge that was used in experiment was collected from the Wastewater Treatment Plant (WWTP) from Piteşti. Chemical characterization of soil and sewage sludge is presented in section Results and discussions.

The factors taken into consideration, parts of experimental model, were: A factor - sewage sludge fertilization with seven degrees representing equivalent doses varying between $0-600 \mathrm{~kg} \mathrm{~N} / \mathrm{ha}$ (a1 unfertilized with sewage sludge; $\mathbf{a} 2$ - fertilization with sewage sludge corresponding to $100 \mathrm{~kg} \mathrm{~N} / \mathrm{ha}$; $\mathbf{a} 3$ - fertilization with sewage sludge corresponding to $200 \mathrm{~kg} \mathrm{~N} / \mathrm{ha}$; $\mathbf{a} 4$ - fertilization with sewage sludge corresponding to $300 \mathrm{~kg} \mathrm{~N} / \mathrm{ha}$; a5 - fertilization with sewage sludge corresponding to $400 \mathrm{~kg} \mathrm{~N} / \mathrm{ha} ; \mathbf{a 6}$ fertilization with sewage sludge corresponding to $500 \mathrm{~kg} \mathrm{~N} / \mathrm{ha} ; \mathbf{a}_{7}$ - fertilization with sewage sludge corresponding to $600 \mathrm{~kg} \mathrm{~N} / \mathrm{ha}$ ) and B factor - mineral fertilization (NPK) with two degrees: b1 $\mathrm{N}_{0} \mathrm{P}_{0} \mathrm{~K}_{0}$ and $\mathbf{b}_{2}-\mathrm{N}_{100} \mathrm{P}_{100} \mathrm{~K}_{100}$.

The same experimental scheme was adopted previously to investigate the suitability use of sewage sludge for sunflower (Helianthus annuus L.) [6] and to evaluate the yield, macroelements and metals accumulation for maize (Zea Mays L.) $[18,19]$.

\subsection{Chemical characterization of soil, sewage sludge and plant}

Analysis methodology for soil and sewage sludge is presented in detail in previous paper [20]. Briefly, according to purposes of the present paper, total forms of metals for soil and sewage sludge samples were performed using atomic absorption spectrometry technique (Thermo Scientific AA Spectrometer) after aqua regia digestion.

In the case of plant analysis, in order to achieve metals concentrations, $1 \mathrm{~g}$ of oven-dried grounded grain sample passed through a sieve of $2 \mathrm{~mm}$ mesh size was digested with $10 \mathrm{~mL}$ from a mixture of acids $\left(\mathrm{HNO}_{3}: \mathrm{H}_{2} \mathrm{SO}_{4}: \mathrm{HClO}_{4}, 5: 1: 1\right)$ till a transparent color appeared [11]. 
Contents of metals $(\mathrm{Cu}, \mathrm{Mn}, \mathrm{Zn}, \mathrm{Cd}, \mathrm{Co}, \mathrm{Pb})$ in oat grain samples were determined after filtering the digested samples by means of atomic absorption spectrometry (Thermo Scientific AA Spectrometer). The calibration curves were plotted using working standards obtained from a multielement stock solution provided by Merck.

\subsection{Data analysis}

Statistical analysis was performed using Tukey's multiple range test at $p \leq 0.05$. Tukey's test compares the means of every treatment to the means of every other treatment. Pearson's $r$ correlation coefficients were calculated by using the scatterplot of correlation data with Excel software.

\section{Results and discussions}

\subsection{Soil and sewage sludge chemical characterization}

The soil used in this experiment was taken from Ao horizon of Luvisol [21] and presented a loam

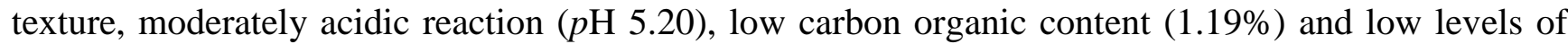
macronutrients: $\mathrm{N}_{\text {total }}-0.140 \%, \mathrm{P}_{\mathrm{AL}}-19 \mathrm{mg} / \mathrm{kg}$ and $\mathrm{K}_{\mathrm{AL}}-40 \mathrm{mg} / \mathrm{kg}$. Complete chemical characterization of sewage sludge is presented in previous paper [20], but from scientific purposes, the average contents of soil and sewage sludge are depicted in Table 1.

Table 1. Average metals contents in soil and sewage sludge

\begin{tabular}{|c|c|c|c|c|}
\hline \multirow[t]{2}{*}{ Metals } & \multirow{2}{*}{$\begin{array}{c}\text { Soil } \\
\text { (average contents) } \\
\mathrm{mg} / \mathrm{kg}\end{array}$} & \multirow{2}{*}{$\begin{array}{c}\text { Sewage sludge } \\
\text { (average contents) } \mathrm{mg} / \mathrm{kg}\end{array}$} & \multicolumn{2}{|c|}{ Restricted value for sewage sludge } \\
\hline & & & $\begin{array}{c}\text { Order 344/2004 Romania } \\
\text { [22] }\end{array}$ & Directive 86/278/EEC [23] \\
\hline $\mathrm{Cd}$ & 0.11 & $\overline{72}$ & 10 & $20-40$ \\
\hline $\mathrm{Co}$ & 6.60 & 6.60 & 50 & - \\
\hline $\mathrm{Cr}$ & 19 & 135 & 500 & - \\
\hline $\mathrm{Cu}$ & 12 & 154 & 500 & $1000-1750$ \\
\hline $\mathrm{Mn}$ & 500 & 400 & - & - \\
\hline $\mathrm{Ni}$ & 15 & 40 & 100 & $300-400$ \\
\hline $\mathrm{Pb}$ & 13 & 106 & 300 & $750-1200$ \\
\hline $\mathrm{Zn}$ & 48 & 1492 & 2000 & $2500-4000$ \\
\hline
\end{tabular}

\subsection{Influence of sewage sludge application on $\mathrm{Cu}, \mathrm{Mn}, \mathrm{Zn}$ contents in oat grains}

The results evidenced that copper levels increased significant with sewage sludge fertilization starting with a dose equivalent with $200 \mathrm{~kg} \mathrm{~N} / \mathrm{ha}$ (Table 2). Mineral fertilization led to significant decrease of copper content in comparison with sewage sludge treatments only, probably due to dilution effect which occurs with the increase of vegetative mass. Mixed treatments generated increases of copper contents in grains but these values are not statistically assured.

Table 2. Influence of sewage sludge application (without/with mineral fertilization) on $\mathrm{Cu}, \mathrm{Mn}$ and $\mathrm{Zn}$ contents in grains

\begin{tabular}{|c|c|c|c|c|c|c|c|c|c|c|}
\hline \multicolumn{2}{|c|}{ Sewage sludge } & \multicolumn{3}{|c|}{$\mathrm{Cu}, \mathrm{mg} / \mathrm{kg}$} & \multicolumn{3}{|c|}{ Mn, mg/kg } & \multicolumn{3}{|c|}{$\mathrm{Zn}, \mathrm{mg} / \mathrm{kg}$} \\
\hline & & $\mathrm{b}_{1}$ & $\mathrm{~b}_{2}$ & Av. (b) & $\mathrm{b}_{1}$ & $\mathrm{~b}_{2}$ & Av. (b) & $\mathrm{b}_{1}$ & $b_{2}$ & Av. (b) \\
\hline$a_{1}$ & $0 \mathrm{~kg} \mathrm{~N} / \mathrm{ha}$ & 5.9 & 5.1 & $5.5 a^{*}$ & 126 & 95 & $111 a^{*}$ & 49 & 33 & $41 a^{*}$ \\
\hline $\mathrm{a}_{2}$ & $100 \mathrm{~kg} \mathrm{~N} / \mathrm{ha}$ & 6.8 & 6.1 & $6.5 \mathrm{ab}$ & 88 & 84 & $86 b$ & 51 & 56 & $54 \mathrm{ab}$ \\
\hline $\mathrm{a}_{3}$ & $200 \mathrm{~kg} \mathrm{~N} / \mathrm{ha}$ & 7.7 & 6.0 & $6.9 \mathrm{bc}$ & 71 & 67 & $69 \mathrm{c}$ & 64 & 65 & $65 \mathrm{bc}$ \\
\hline $\mathrm{a}_{4}$ & $300 \mathrm{~kg} \mathrm{~N} / \mathrm{ha}$ & 8.3 & 7.1 & $7.7 \mathrm{bcd}$ & 54 & 50 & $52 \mathrm{~d}$ & 69 & 76 & $73 c$ \\
\hline $\mathrm{a}_{5}$ & $400 \mathrm{~kg} \mathrm{~N} / \mathrm{ha}$ & 8.3 & 7.6 & $8.0 \mathrm{~cd}$ & 53 & 54 & $54 d$ & 88 & 99 & $94 d$ \\
\hline $\mathrm{a}_{6}$ & $500 \mathrm{~kg} \mathrm{~N} / \mathrm{ha}$ & 8.4 & 7.9 & $8.2 \mathrm{~d}$ & 40 & 52 & $46 \mathrm{~d}$ & 100 & 116 & 108de \\
\hline $\mathrm{a}_{7}$ & $600 \mathrm{~kg} \mathrm{~N} / \mathrm{ha}$ & 8.6 & 8.3 & $8.5 \mathrm{~d}$ & 38 & 50 & $44 d$ & 111 & 126 & $119 \mathrm{e}$ \\
\hline \multicolumn{2}{|c|}{ Av. (a) } & $7.7 \mathrm{a}^{*}$ & $6.9 \mathrm{~b}$ & - & $67 a^{*}$ & $65 a$ & - & $76 a^{*}$ & $82 b$ & - \\
\hline
\end{tabular}

b1 - corresponds to $\mathrm{N}_{0} \mathrm{P}_{0} \mathrm{~K}_{0}$ (without mineral fertilization); $\mathbf{b}_{2}$ - corresponds to $\mathrm{N}_{100} \mathrm{P}_{100} \mathrm{~K}_{100}$ (mineral fertilization); Av. - average

* Mean values accompanied by same letter (a or b) does not present significant differences (Tukey multiple comparison test - significance level 0.05) 
According to manganese levels found in oat grains, it may be concluded that fertilization with sewage sludge has produced a significant decrease of manganese, this trend being accentuated up to the equivalent dose of $300 \mathrm{~kg} \mathrm{~N} / \mathrm{ha}$ (Table 2). Mineral fertilization did not produced significant changes for manganese content in oat grains. Also, after application of sewage sludge associated with mineral fertilizers it was observed that manganese levels are similar as those obtained after sewage sludge application.

Concerning zinc contents in oat grains, the results indicated an increase with sewage sludge dose and also with mineral fertilization (Table 2). The increases are statistically assured starting with a dose equivalent with $200 \mathrm{~kg} \mathrm{~N} / \mathrm{ha}$. For fertilized variants with a dose of $600 \mathrm{~kg} \mathrm{~N} / \mathrm{ha}$, zinc levels are 2.9 times higher than unfertilized variant.

The contents of copper, manganese and zinc found for oat grains in this study are within the values of previous surveys developed for cereal grains [24] and oat grains [25-28].

The content of $\mathrm{Cu}, \mathrm{Mn}$ and $\mathrm{Zn}$ in oat grains was very significantly correlated with $\mathrm{N}$ doses determined by applying sludge in increasing doses with or without mineral fertilizer (Figures 1, 2, 3).

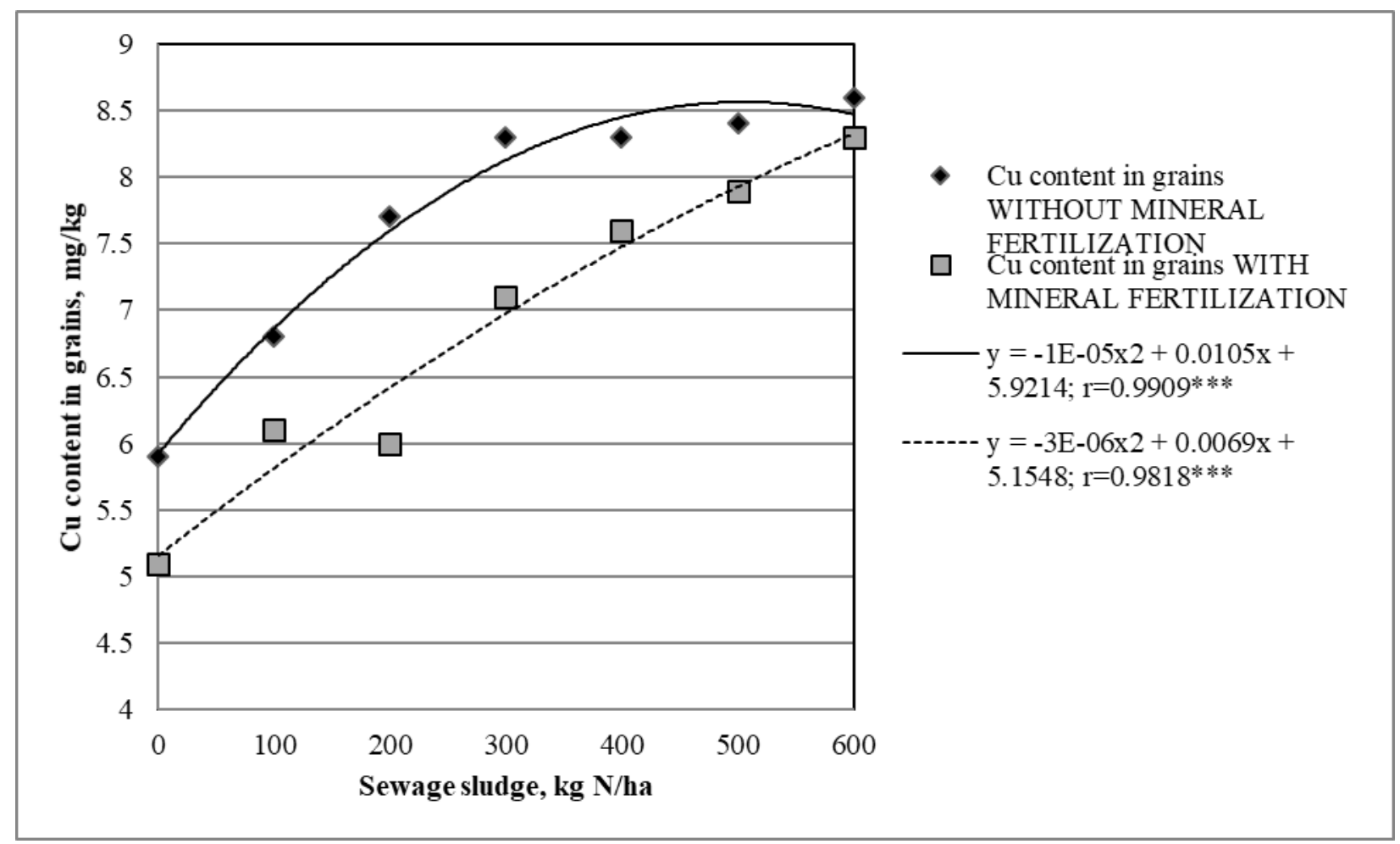

Figure 1. Correlation between $\mathrm{Cu}$ content in oat grains and applied nitrogen doses $(* * *$ very strong correlation, $\mathrm{p}<0.001)$ 


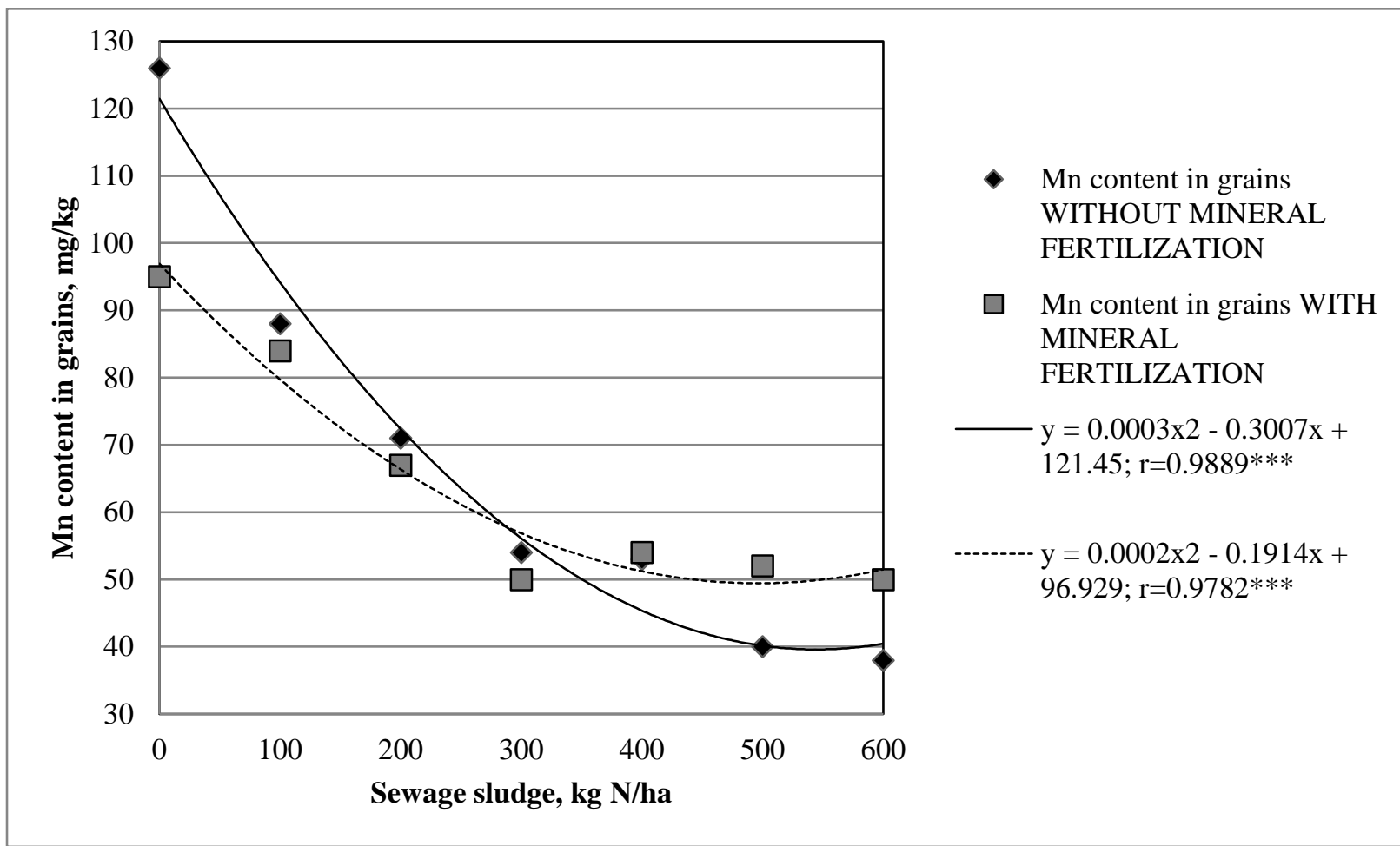

Figure 2. Correlation between Mn content in oat grains and applied nitrogen doses $(* * *$ very strong correlation, $\mathrm{p}<0.001)$

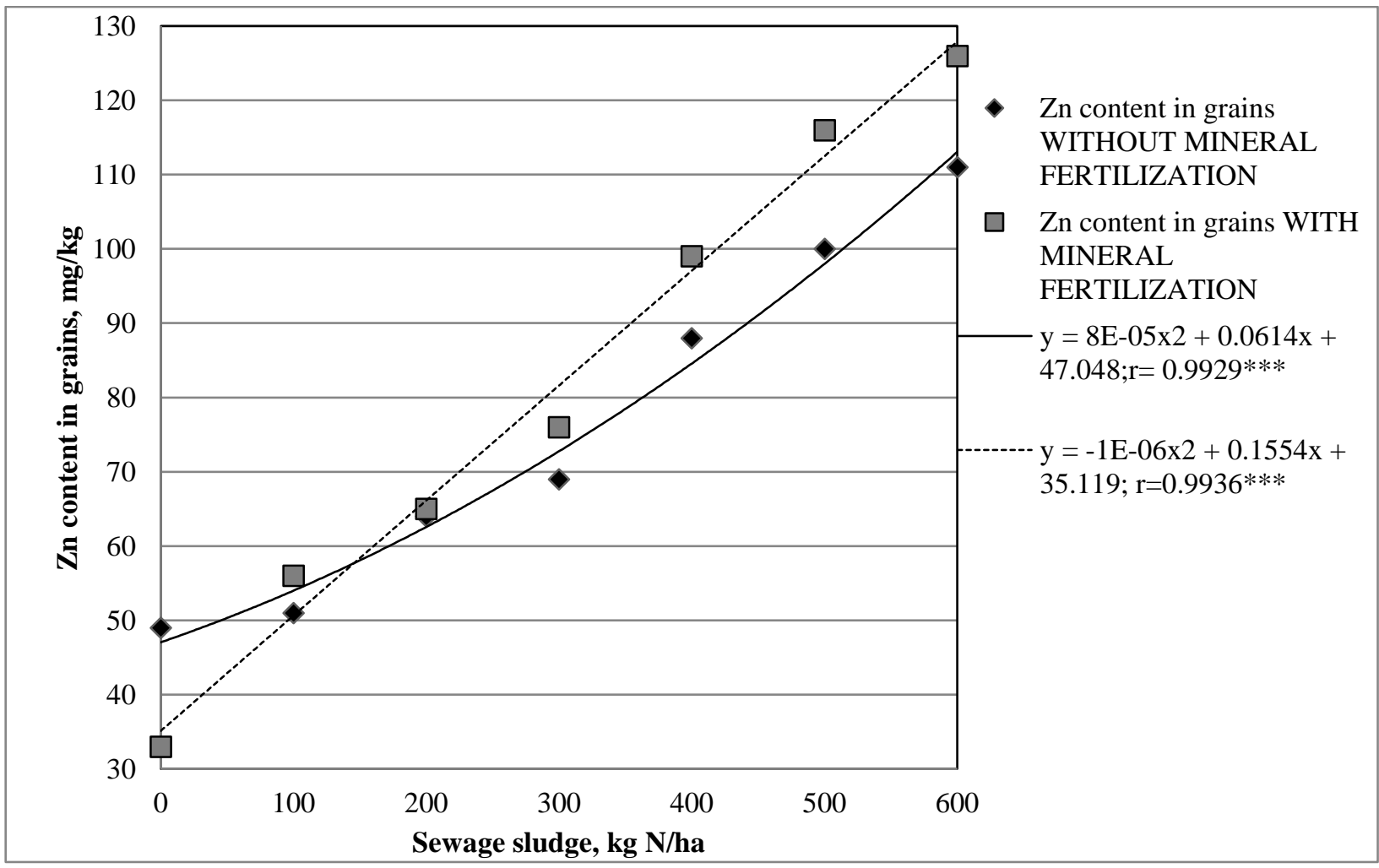

Figure 3. Correlation between $\mathrm{Zn}$ content in oat grains and applied nitrogen doses $(* * *$ very strong correlation, $\mathrm{p}<0.001)$ 


\subsection{Influence of sewage sludge application on cadmium, cobalt and lead contents in oat grains}

Application of sewage sludge with a load of cadmium of $72 \mathrm{mg} / \mathrm{kg}$, which is 7.2 times higher than limit value for sewage sludge [22], generated an alarming increase of cadmium in oat grains, higher than value of $1 \mathrm{mg} / \mathrm{kg}$ (when the grains are used for animal feed) [23], starting with equivalent dose of $200 \mathrm{~kg} \mathrm{~N} / \mathrm{ha}$ (Table 3). When sewage sludge was applied in an equivalent dose of $600 \mathrm{~kg} \mathrm{~N} / \mathrm{ha}$ it was observed an increase of cadmium levels of 14 times in comparison with unfertilized variant.

Mixed application of mineral and organic fertilizers produced an increase of cadmium in oat grains, more evident than in the case of sewage sludge application only. In this case, the level of $1 \mathrm{mg} \mathrm{Cd} / \mathrm{kg}$ was also achieved at $200 \mathrm{~kg} \mathrm{~N} / \mathrm{ha}$ dose. Accordingly, on the basis of these findings, application of sewage sludge in an equivalent dose higher than $200 \mathrm{~kg} \mathrm{~N} / \mathrm{ha}$ it is not recommended. Also the limit (0.1 mg Cd/kg wet weight) imposed by European regulation EC 466/2001 [29], concerning the presence of some contaminants in foodstuffs for humans, is exceeded.

Cadmium contents for oat grains reported by other researchers are much lower than those evidenced in present study, respectively $0.0045-0.0550 \mathrm{mg} / \mathrm{kg}$ [27] and $0.008-0.023 \mathrm{mg} / \mathrm{kg}$ [28]. As reported by Brunetti et al. [30], cadmium levels ranged from 0.03 to $0.1 \mathrm{mg} / \mathrm{kg}$ from wheat grains and below detection limit to $0.02 \mathrm{mg} / \mathrm{kg}$ for barley grains.

The detrimental effects of excessive cadmium levels on plant growth had been widely documented [31]. Thus, Yourtchi and Bayat [32] reported for wheat, reduction in nutrient content of plants and decline in seed germination, meanwhile Wang and co-workers [33] observed in the case of maize the inhibition of root growth and reduced shoot development. For oat, a study [34] evidenced that a dose of $10 \mathrm{mg} \mathrm{Cd} / \mathrm{kg}$ soil significantly decreased the yield of oat straw and roots. Doses of $30 \mathrm{and} 40 \mathrm{mg}$ $\mathrm{Cd} / \mathrm{kg}$ soil significantly lowered oat grain yields.

For animals and humans, cadmium has no significant biological importance and contrariwise are highly dangerous when found in environment, its toxicity being due changes in the conformational structure of nucleic acids or by interference with oxidative phosphorylation and osmotic balance [31].

With sewage sludge doses, cobalt concentration in oat grains present an increase tendency which is not statistically assured (Table 3). Association of mineral with organic fertilization presents the same trend as sewage sludge application only. Cobalt contents of oat grains are between normal limits and are in agreement with results reported by Kan [24] for cereal grains $(0.2-0.3 \mathrm{mg} / \mathrm{kg})$.

Table 3. Influence of sewage sludge application (without/with mineral fertilization) on $\mathrm{Cd}, \mathrm{Co}$ and $\mathrm{Pb}$ contents in grains

\begin{tabular}{|c|c|c|c|c|c|c|c|c|c|c|}
\hline \multicolumn{2}{|c|}{ Sewage sludge } & \multicolumn{3}{c|}{ Cd, mg/kg } & \multicolumn{3}{c|}{ Co, mg/kg } & \multicolumn{3}{c|}{ Pb, mg/kg } \\
\cline { 3 - 12 } \multicolumn{2}{|c|}{} & $\mathrm{b}_{1}$ & $\mathrm{~b}_{2}$ & Av.(b) & $\mathrm{b}_{1}$ & $\mathrm{~b}_{2}$ & Av.(b) & $\mathrm{b}_{1}$ & $\mathrm{~b}_{2}$ & Av.(b) \\
\hline $\mathrm{a}_{1}$ & $0 \mathrm{~kg} \mathrm{~N} / \mathrm{ha}$ & 0.28 & 0.20 & $0.24 \mathrm{a}^{*}$ & 0.20 & 0.24 & $0.22 \mathrm{a}^{*}$ & 1.30 & 1.27 & $1.29 \mathrm{a}^{*}$ \\
\hline $\mathrm{a}_{2}$ & $100 \mathrm{~kg} \mathrm{~N} / \mathrm{ha}$ & 0.57 & 0.68 & $0.63 \mathrm{ab}$ & 0.22 & 0.25 & $0.24 \mathrm{a}$ & 1.49 & 1.48 & $1.49 \mathrm{ab}$ \\
\hline $\mathrm{a}_{3}$ & $200 \mathrm{~kg} \mathrm{~N} / \mathrm{ha}$ & 1.03 & 1.11 & $1.07 \mathrm{~b}$ & 0.22 & 0.27 & $0.25 \mathrm{a}$ & 1.53 & 1.51 & $1.52 \mathrm{ab}$ \\
\hline $\mathrm{a}_{4}$ & $300 \mathrm{~kg} \mathrm{~N} / \mathrm{ha}$ & 1.49 & 1.83 & $1.66 \mathrm{c}$ & 0.24 & 0.29 & $0.27 \mathrm{a}$ & 1.63 & 1.58 & $1.61 \mathrm{ab}$ \\
\hline $\mathrm{a}_{5}$ & $400 \mathrm{~kg} \mathrm{~N} / \mathrm{ha}$ & 2.09 & 2.38 & $2.24 \mathrm{~d}$ & 0.28 & 0.33 & $0.31 \mathrm{a}$ & 1.63 & 1.56 & $1.60 \mathrm{ab}$ \\
\hline $\mathrm{a}_{6}$ & $500 \mathrm{~kg} \mathrm{~N} / \mathrm{ha}$ & 2.66 & 2.80 & $2.73 \mathrm{~d}$ & 0.32 & 0.34 & $0.33 \mathrm{a}$ & 1.90 & 1.83 & $1.87 \mathrm{bc}$ \\
\hline $\mathrm{a}_{7}$ & $600 \mathrm{~kg} \mathrm{~N} / \mathrm{ha}$ & 2.99 & 3.77 & $3.38 \mathrm{e}$ & 0.35 & 0.35 & $0.35 \mathrm{a}$ & 2.20 & 2.13 & $2.17 \mathrm{c}$ \\
\hline \multicolumn{2}{|c|}{ Av. (a) } & $1.59 \mathrm{a}^{*}$ & $1.82 \mathrm{~b}$ & - & $0.26 \mathrm{a}$ & $0.30 \mathrm{a}$ & - & $1.67 \mathrm{a}^{*}$ & $1.62 \mathrm{a}$ & - \\
\hline
\end{tabular}

$\mathbf{b}_{1}$ - corresponds to $\mathrm{N}_{0} \mathrm{P}_{0} \mathrm{~K}_{0}$ (without mineral fertilization); $\mathbf{b}_{2}$ - corresponds to $\mathrm{N}_{100} \mathrm{P}_{100} \mathrm{~K}_{100}$ (mineral fertilization); Av. - average * Mean values accompanied by same letter (a or b) does not present significant differences (Tukey multiple comparison test - significance level 0.05)

The correlations between content of $\mathrm{Cd}, \mathrm{Co}$ and $\mathrm{Pb}$ from oat grains and increasing doses of $\mathrm{N}$ corresponding to sewage sludge applied without/with mineral fertilizer indicates coefficients of correlation very significant (Figures 4, 5, 6). 


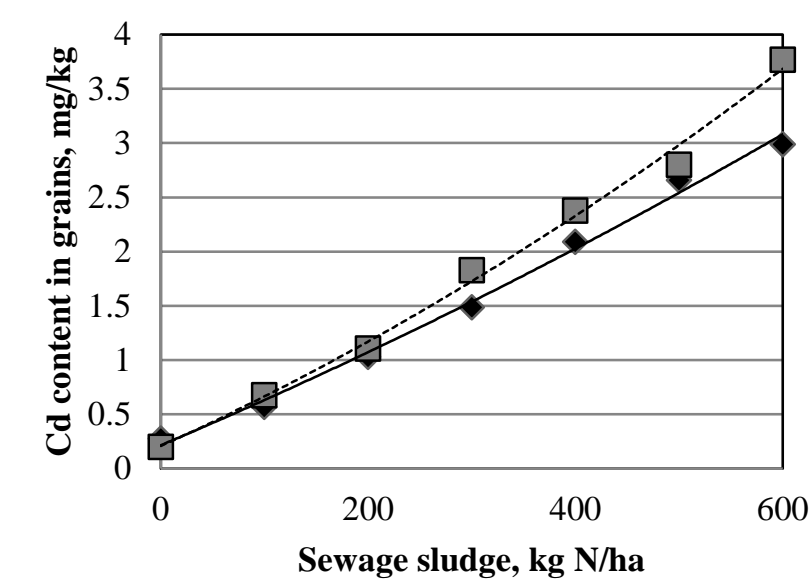

- Cd content in grains WITHOUT MINERAL FERTILIZATION

$\square \quad$ Cd content in grains WITH MINERAL FERTILIZATION

Figure 4. Correlation between $\mathrm{Cd}$ content in oat grains and applied nitrogen doses $(* * *$ very strong correlation, $\mathrm{p}<0.001)$

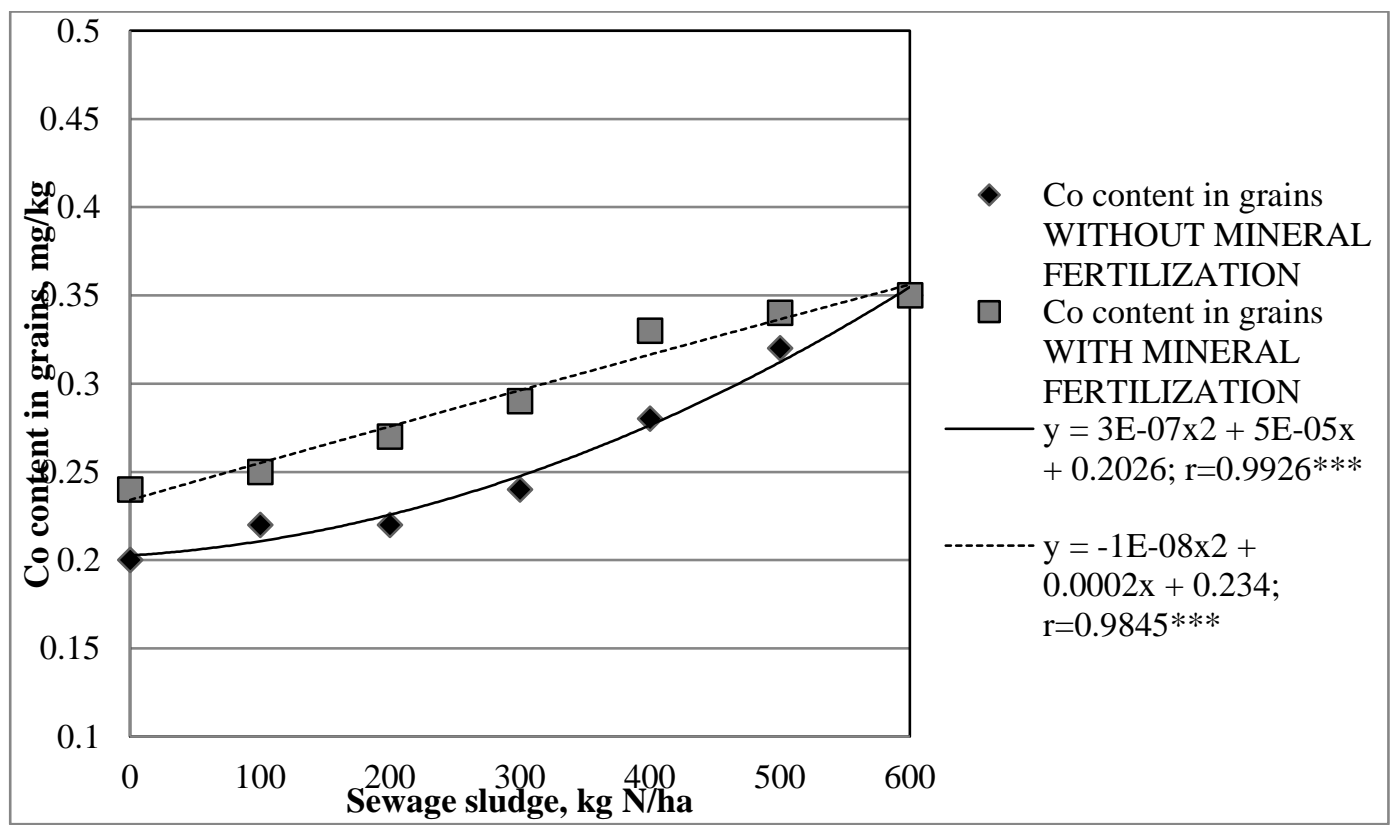

Figure 5. Correlation between Co content in oat grains and applied nitrogen doses $(* * *$ very strong correlation, $\mathrm{p}<0.001)$ 


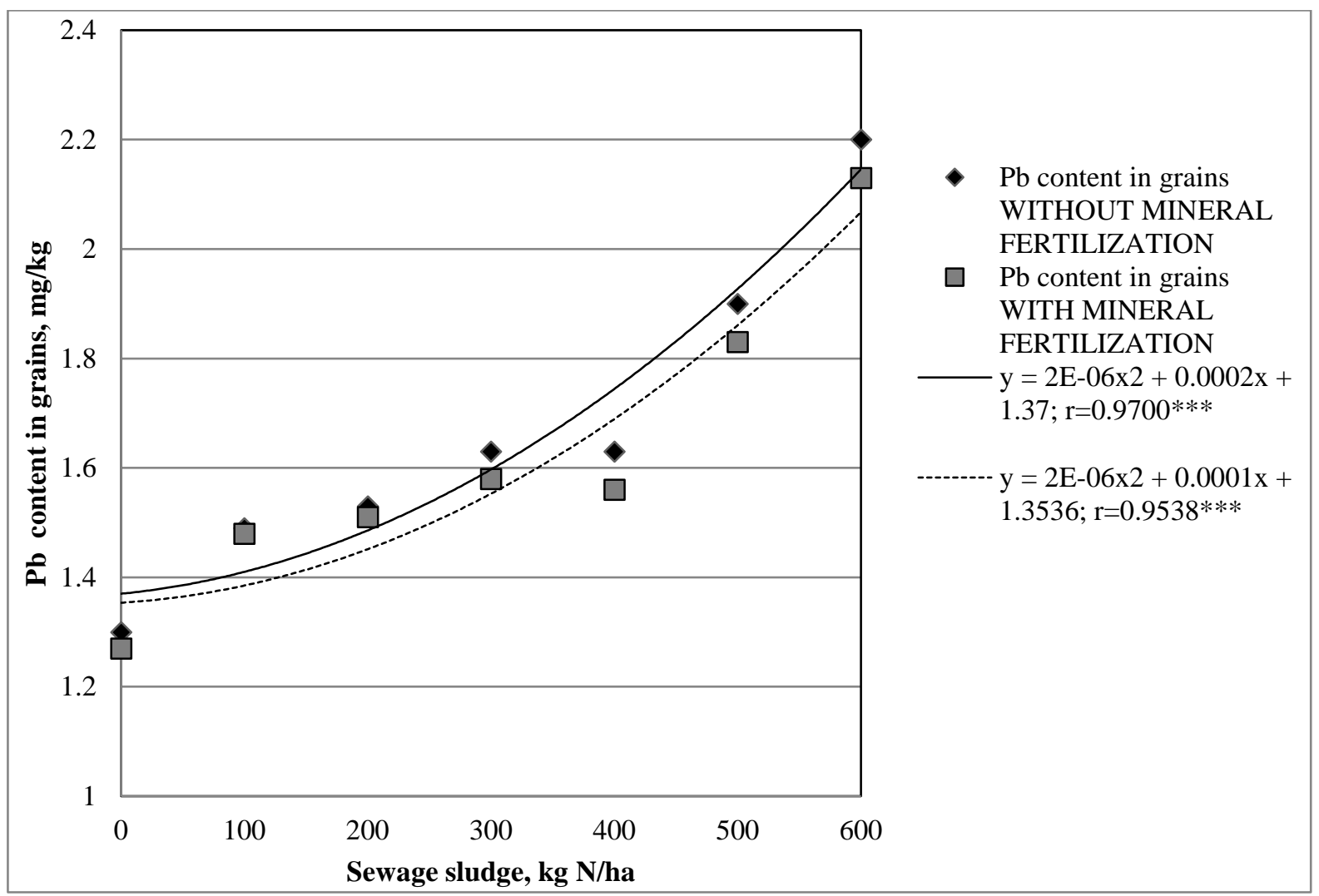

Figure 6. Correlation between $\mathrm{Pb}$ content in oat grains and applied nitrogen doses $(* * *$ very strong correlation, $\mathrm{p}<0.001)$

Application of sewage sludge in an equivalent doses of 500 and $600 \mathrm{~kg} \mathrm{~N} / \mathrm{ha}$ generated a significant increase of lead content in oat grains (Table 3). Mixed fertilization did not produce a significant increase of grain lead content. Lower levels of lead in wheat grains $(0.15-0.63 \mathrm{mg} / \mathrm{kg})$ and barley grains $(0.39-0.75 \mathrm{mg} / \mathrm{kg})$ were reported by Brunetti et al. [30]. Zhao et al. [35] reported for wheat grains a concentration of $1.63 \mathrm{mg} \mathrm{Pb} / \mathrm{kg}$.

Having in view the Commission Regulation EC 466/2001 [29], the found values for lead levels in oat grains destined for human consumption are over imposed limit $(0.2 \mathrm{mg} \mathrm{Pb} / \mathrm{kg}$ wet weight $)$.

Considering that the entry of lead into the food chain is of great concern because of its health related consequences, it is recommended to avoid the use of the oat grains from this experiment for human consumption.

\section{Conclusions}

In summary, the results of the research are presented below.

- Copper and zinc levels in oat grains increased significant with fertilization with sewage sludge starting with a dose equivalent with $200 \mathrm{~kg} \mathrm{~N} / \mathrm{ha}$, meanwhile manganese concentration in oat decreased with sewage sludge application, this behavior being accentuated up to equivalent dose of $300 \mathrm{~kg} \mathrm{~N} / \mathrm{ha}$.

- Mineral fertilization led to significant decrease of copper content in comparison with sewage sludge treatments only, but mixed organic-mineral treatments generated increases of copper contents in grains.

- Cadmium content of oat grains exceeds the limit value of $1 \mathrm{mg} / \mathrm{kg}$, this situation being possible because of high cadmium content of sewage sludge $(72 \mathrm{mg} / \mathrm{kg})$. Mixed application of mineral and organic fertilizers produced an increase of cadmium in oat grains, more evident than in the case of sewage sludge application only. 
- Cobalt contents of oat grains after sewage sludge application are between normal values; the cobalt concentration increased with sewage sludge doses.

- Lead levels also increased with sewage sludge application and the obtained values exceed for all variants the limit imposed for cereals destined for human consumption.

\section{References}

1.URBANIAK, M., WYRWICKA, A., TOLOCZKO, W., SERWECINSKA, ZIELINSKI M., Sci.Total Environ., 586, 2017, p.66.

2.NEAMT, I., IONEL, I., FLORESCU, C., Rev.Chim., 63, (7), 2012, 739.

3.IORDACHE, S., DUNEA, D., IANACHE, C., Rev.Chim.,65, (2), 2014, 242.

4.TSADILAS, C.D., MATSI, T., BARBAYIANNIS, N., DIMOYIANNIS, D., Commun. Soil Sci. Plant Anal., 26, 1995, p.2603.

5.MORERA, M.T., ECHEVERRIA, J., GARRIDO, J., Can. J. Soil Sci., 82, 2002, p.433.

6.MIHALACHE, M., ILIE, L., MADJAR, R.M., CALIN, C., SCAETEANU VASILE, G., Rev.Chim., 66, (7), 2015, 951.

7.SINGH, R.P., AGRAWAL, M., Ecotoxicol. Environ. Saf.,73, 2010, p.632.

8.WANG, X., CHEN, T., GE, Y., JIA, Y., J. Hazard.Mater.,160, 2008, p.554.

9.HERNANDEZ, T., MORENO, J., COSTA, F., Soil Sci. Plant Nutr., 37(2), 1991, p.201.

10.BElHAJ, D., Elloumi, N., JERBI, B., ZOUARI, M., ABDALlAH, F.B., AYADI, H., KALLEL, M., Environ. Sci.Pollut. Res., 23(20), 2016, p. 20168.

11.SINGH, R.P., AGRAWAL, M., Chemosphere, 67, 2007, p.2229.

12.KAMAL, A.T.M.M., ISLAM, M.M., HOSSAIN, M.S., ULLAH, S.M., Bangladesh J. Sci. Res., 26(1\&2), 2013, p.57.

13.KOMINKO, H., GORAZDA， K., WZOREK， Z., L.Environ.Manage., 248, 2019, https://doi.org/10.1016/j.jenvman.2019.109283.

14.HUDCOVA, H., VYMAZAL, J., ROZKOSNY, M., Soil Water Res., 14, 2019, 104.

15.EID, E., ALAMRI, S., SHALTOUT, K., GALAL, T., AHMED, M., BRIMA, E., SEWELAM, N., Food Energy Secur., 00:e197, 2020, https://doi.org/10.1002/fes3.197.

16.MIHALACHE, M., ILIE, L., MADJAR, R., Revue Roum. Chim., 59(2), 2014, p.81.

17.ILIE, L., VASILE SCAETEANU, G., MIHALACHE, M, MADJAR, M., CĂLIN, C., Rev. Chim., 65, (12), 2014, p.1485.

18.ILIE, L., MIHALACHE, M., MADJAR, R.M., CALIN, C., VASIlE SCAETEANU, C., Rev. Chim., 69, (3), 2018, 561.

19.ILIE, L., MIHALACHE, M., VASILE SCAETEANU, G., MADJAR, R.M., POPOVICI, D.R., Rev. Chim., 69, (5), 2018, 1166.

20.ILIE, L., MIHALACHE, M., MADJAR, R.M., CALIN, C., VASILE SCAETEANU, G., Rev.Chim., accepted for publication.

21.***FAO.1998. World Reference Base for Soil Resources, by ISSS-ISRIC-FAO. World Soil Resources Report, No. 84, Rome.

22.***Order of the Minister of Agriculture, Forests, Waters and Environment no.344/2004 for the approval of Technical Guidelines on the protection of the environment.

23.***Council Directive 86/278/EEC of 12 June 1986 on the protection of the environment, and in particular of the soil, when sewage sludge is used in agriculture.

24.KAN, A., Rec.Nat.Prod.J., 9(1), 2015, p.124.

25.RUBENE, D., KUKA, P., https://llufb.llu.lv/conference/Research-for-Rural-Development/ 2007/ Pages_075-078.pdf (accessed at 04.09.2019).

26.CIOLEK, A., MAKARSKA, E., WESOLOWSKI, M., CIERPIALA, R., J.Elem., 2012, p.181. DOI: 10.5601/jelem.2012.17.2.02.

27.JAKOBSONE, I., KANTANE, I., ZUTE, S., JANSONE, I., BARTKEVICS, V., Proceedings of the Latvian Academy of Sciences, section B, 69, no.4, 2015, p.152. 
28.JAKOBSONE, I., ZUTE, S., BLEIDERE, M., KANTANE, I., ECE, L., BARTKEVICS, V., Zemdirbyste-Agriculture, 106, no.1, 2019, p.21.

29.***Comission Regulation 466/2001/EC of 8 March 2001 setting maximum levels for certain contaminants in foodstuffs.

30.BRUNETTI, G., FARRAG, K., SOLER-ROVIRA, P., FERRARA, M., NIGRO, F., SENESI, N., J.Plant.Interact., 7(2), 2012, p.160.

31.OKEREAFOR, U., MAKHATHA, M., MEKUTO, L., UCHE-OKEREAFOR, N., SEBOLA, T., MAVUMENGWANA, V., Int.J.Environ. Res. Public Health, 17, 2020, 2204.

32.YOURTCHI, M.S., BAYAT, H.R., Int.J.Agric.Crop Sci., 6, 2013, 1099.

33.WANG, W., ZOU, J., DUAN, X., JIANG, W., LIU, D., Bioresour.Technol., 98, 2007, 82-88.

34.ROLKA, E., J.Elem., 20(4), 2015, 975.

35.ZHAO, F.J., ADAMS, M.L., DUMONT, C., McGRATH, S.P. CHAUDRI, A.M., NICHOLSON, F.A., CHAMBERS, B.J., SINCLAIR, A.H., Environ.Pollut., 131, 2004, p.461.

Manuscript received: 28.11 .2019 